The One-State Condition 
Stanford Studies in Middle Eastern and Islamic Societies and Cultures 


\section{The One-State Condition}

OCCUPATION AND DEMOCRACY IN ISRAEL/PALESTINE

Ariella Azoulay and Adi Ophir

Translated by Tal Haran 
Stanford University Press

Stanford, California

English translation $\oplus_{2013}$ by the Board of Trustees of the Leland Stanford Junior University. All rights reserved.

A longer version of this work was originally published in Hebrew in 2008 under the title Mishtar zeh she'eno ehad: kibush ve'demokratyah ben ha'yam la'nahar [This Regime That Is Not One: Occupation and Democracy Between the Sea and the River] @ 2008, Resling, Tel Aviv.

Financial support for the translation was provided by the Duke University Center for International Studies.

No part of this book may be reproduced or transmitted in any form or by any means, electronic or mechanical, including photocopying and recording, or in any information storage or retrieval system without the prior written permission of Stanford University Press.

Printed in the United States of America on acid-free, archival-quality paper

Library of Congress Cataloging-in-Publication Data

Azoulay, Ariella, author.

[Mishtar zeh she-eno ehad. English]

The one-state condition : occupation and democracy in Israel/Palestine / Ariella Azoulay and Adi Ophir ; translated by Tal Haran.

pages $\mathrm{cm}$.--(Stanford studies in Middle Eastern and Islamic societies and cultures)

Abridged translation of: Mishtar zeh she-eno ehad : kibush ve-demokratyah ben ha-yam la-nahar (1967-).

Includes bibliographical references and index.

ISBN 978-0-8047-7591-5 (cloth : alk. paper)--ISBN 978-0-8047-7592-2 (pbk. : alk. paper)

1. Arab-Israeli conflict--1993---Influence. 2. Israel--Politics and government--1967-1993.

3. Israel--Politics and government--1993- 4. Palestinian Arabs--Government policy--Israel.

5. Democracy--Israel. 6. Military occupation--Social aspects--West Bank. 7. Military occupation--Social aspects--Gaza Strip. 8. Israel-Arab War, 1967--Occupied territories. I. Ophir, Adi, author. II. Title. III. Series: Stanford studies in Middle Eastern and Islamic societies and cultures.

DS119.76.A9813 2012

956.95'3044--dc23

2012022025

Typeset by Bruce Lundquist in 10/14 Minion 